\title{
Study on genes of the serotonergic system and suicidal behavior: protocol for a case-control study in Mexican population
}

\author{
Carlos Alfonso Tovilla-Zárate ${ }^{1 *}$, Thelma Beatriz González-Castro², Isela Juárez-Rojop², Sherezada Pool García ${ }^{3}$, \\ Martha Patricia Velázquez-Sánchez ${ }^{3}$, Mario Villar-Soto ${ }^{4}$, Alma Genis ${ }^{5}$, Humberto Nicolini ${ }^{5}$, \\ María Lilia López-Narváez ${ }^{6,7}$ and María Antonia Jiménez-Santos ${ }^{1}$
}

\begin{abstract}
Background: Suicidal behavior is a leading cause of injury and death worldwide. Several studies have provided a possible relationship between genetic factors and suicidal behavior. Also, these studies have shown evidence for altered serotonergic neural transmission in the pathogenesis of suicidal behavior. In addition, genes pertaining to the serotonergic system have been proposed as candidates to establish biological correlates between suicidal behavior and the serotonergic system. The most studied genes are SCL6A4, HTR2A, HTR2C, HTR1A, HTR1B, TPH-1, and TPH-2. To get a comprehensive understanding of the association with suicidal behavior we will conduct genotype assays studies in a Mexican population.

Methods/Design: We will conduct a case-control study. The population sample will comprise adolescent and adult patients admitted for attempted of suicide and diagnosed by a psychiatrist. A peripheral blood sample will be taken from all the subjects (cases and controls). Genomic DNA from the leukocytes blood sample will be extracted. The genotypes of interest are distributed in the following genes: SCL6A4, HTR2A, HTR1A, HTR1B, HTR2C, TPH-2 and $\mathrm{TPH}-1$. All the samples will be analyzed using a polymerase chain reaction (PCR) end-point method. We will evaluate the Hardy-Weinberg Equilibrium. The chi-squared test or Fisher's exact test will be used to compare genotype and allele frequencies between control and case groups. The Quanto 1.2 software will measure the sample size of the association. For all the association analyses the level of significance will be set at $p=0.05$ and the confidence interval at $95 \%$.
\end{abstract}

Discussion: Suicidal behavior has been increase in Mexico, principally in young population. Our study will demonstrate the association between serotoninergic genes and suicide behavior in Mexican population.

Keywords: Suicide, Serotonin receptor, Association, Mexican population

\section{Background}

Suicide is defined as the act of killing oneself in a voluntary way. The World Health Organization (WHO) classifies this action as a deliberate self-harm against oneself [1]. Suicidal behavior (SB) includes from just the thought of planning the suicide, attempt to kill oneself, to the consummation of the act $[2,3]$. WHO estimates that suicide represents at least $2 \%$ of the deaths in the world

\footnotetext{
*Correspondence: alfonso_tovillaz@yahoo.com.mx

'División Académica Multidisciplinaria de Comalcalco, Ranchería Sur, Cuarta Sección, CP 86650 Comalcalco, Tabasco, México

Full list of author information is available at the end of the article
}

$[1,4]$. According to some statistics people aged 75 or older resort to suicide three times more often than youngsters. However, suicide among young people between 12 and 25 years old has been on the rise around the world [5]. Compared to other countries, Mexico in 1980-1999 exhibited an increase in suicide of $90.3 \%$ in men and $25.5 \%$ in women [4,6-8]. Moreover, in the period 1990 to 2000 the increase was $150 \%$ in the young population $[6,9]$, and according to a recent statistic in $47 \%$ of the individuals between 14 and 19 years old suicide is the second cause of death among the young Mexican population. In particular the state of Tabasco 
occupies the third place in these figures and the first in the southeastern region of the country of patients who presented suicidal behavior $[5,8]$.

Suicide is considered a multifactorial event that involves biological, social, individual and environmental factors [10]. Suicidal behavior has been associated among many risk factors with psychiatric disease, such as anxiety disorder, major depression, substance abuse (alcohol and drugs), personality disorder and schizophrenia [11]. Other risk factors for suicidal behavior are marital status, unemployment, adverse events, child abuse and neurological disease [12]. However, sociocultural events do not provide a complete explanation for suicidal behavior. As a result it has been accepted that suicide will be fully understood when the interaction between biological and environmental factors are taken into consideration [13]. One factor that has been involved in suicidal behavioral is genetic risk. This evidence is based on genetic epidemiology studies that include twin [14], family $[10,15]$ and adoption studies [16].

The genes highlighted in the association with suicidal behavior are those that encode proteins of the serotonergic system. Moreover, low 5-hydroxyindoleacetic acid concentration (5-HIIA) in cerebrospinal fluid of depressed suicide attempters and in brain stems of completed suicides has been reported [17-19].

The main genes implicated in suicidal behavior are associated with serotonin production and its transporter. The serotonin transporter (SLC6A4) has been the most studied in relation to SB. This gene is located in region 17q11.1-17q12 [20]. One of the polymorphisms of SLC6A4 is 5-HTTLPR, situated in the promoter region and characterized by the $44 \mathrm{bp}$ insert (alleles I)/ deletion (allele s) $[21,22]$. The expression of this gene is regulated by elements in the promoter region. The literature describes that the homozygous genotype to allele I shows more transcriptional activity than genotypes with one or two ss alleles [22-25]. This finding led to an association between the s allele polymorphism and anxiety disorder, depression and suicidal behavior, among other diseases [26-28]. Recently, a meta-analysis of 44 studies reported that carriers of the short allele exhibited increased risk for suicidal behavior [29].

Other genes studied are serotonin receptors, mainly HTR2A, HTR1B and HTR2C. Several reports have analyzed the possible association of C102T HTR2A polymorphism with $\mathrm{SB}$ and have observed an excess of the C/C genotype in patients with suicide attempts [29-31]. Similarly, the decreased number of 5 -HT1B receptors in the prefrontal cortex in patients with SB locates this receptor as a candidate gene study [32]. The receptor 5HT2C has been studied in several Caucasian and Asian populations with significant association [33,34].

Other genes that may play a role in SB pathogenesis are tryptophan hydroxylase (TPH) and monoamine oxidase A (MAO-A) [33]. The TPH gene has two known isoforms: TPH2, which is expressed in brain and TPH1, expressed mainly in the periphery. To date there are more than 30 reports of these two isoforms in association with SB. With regard to MAO-A, most studies have identified a VNTR in the promoter region, which is correlated with suicide victims [35]. On the other hand, the literature also suggests that epigenetic alterations in specific genes are associated with $\mathrm{SB}$, as has been observed in other psychiatric diseases. In addition, DNA methylation can influence gene expression in neurons and glial cells. As a result, alterations in personality traits have been described [20,36,37].

\section{Aims and objectives}

This article focuses on the analysis of SB in the Mexican population, particularly in the Tabasco state. The aim of this study is to determine the association of several serotonergic genes (SCL6A4, HTR2A, HTR2C, HTR1A, HTR1B, TPH-1, and TPH-2) with suicidal behavior in Mexicans.

\section{Methods/Design Study patients}

The population sample chosen for the study will comprise adolescent and adult patients (14-60 years old) admitted to the Regional Hospital of Comalcalco, Tabasco and Hospital "Gustavo A. Rovirosa P" and diagnosed with SB by a psychiatrist. We expect to recruit 500 cases. The inclusion/exclusion criteria will be the following: participants must be Mexican subjects descending from Mexican parents and grandparents, current substance abuse, history of substance dependence, history of bipolar disorder, concomitant medical or neurological illness, and intellectual disability. Also, the authorized control group will consist of physically healthy subjects on medical evaluation, with no manifested psychiatric problems, as assessed in brief interviews by psychiatrists; subjects will be recruited from the blood donor center of the same hospital. We expect to recruit 500 controls. SB diagnosis will be based on the DSM-IV instrument; disorders pertaining to Axis I, II and III will be considered. For the control group, a systematic interview will serve to obtain a detailed medical and psychiatric history. The time frame the recruitment of cases-controls will be November 2012 to November 2015.

\section{Ethics statement}

Written informed consent will be obtained from all subjects after they are given a detailed and extensive description of the study; they will not receive any economical remuneration. The study was approved by two Ethics Committee (Hospital General de Comalcalco and Hospital Dr. Gustavo A. Rovirosa Perez) and Research Committee 
of the university the Tabasco, México (DAMC-UJAT). Also, the study will be carried out in accordance with the ethical standards convened in the 1964 Declaration of Helsinki.

\section{Genotype assays}

A peripheral blood sample will be taken from all the subjects (cases and controls). Genomic DNA from the leukocytes blood sample will be extracted using a modified version of the protocol by Lahiri [38-40]. The genotypes of interest are distributed in the following genes: SCL6A4 (HTTLPR, rs25531, rs6355), HTR2A (rs6313, rs6311, rs6314), HTR1A (rs6295, rs1423691, rs878567), HTR1B (rs6296), HTR2C (rs547536, rs2192372, rs42 72555, rs6318, rs2428707), ТPH-2 (rs7305115) and TPH-1 (rs179913, rs1800532). All the samples will be analyzed using a polymerase chain reaction (PCR) endpoint method. The final volume of the PCR reaction for HTR2A, HTR1A, HTR2C, TPH-2 and TPH-1 will be $5 \mu \mathrm{L}$ and will consist of $20 \mathrm{ng}$ genomic DNA, 2.5 Fluorescence Labeling (FL) TaqMan Master Mix, and 2.5 FL 20x Assay. The amplification will be performed in 96well plates using the TaqMan Universal Thermal Cycling Protocol. After the PCR endpoint procedure, fluorescence intensity will be measured with the 7500 Real-Time PCR system using SDS v2.1 software (Applied Biosystems). All genotyping will be carried out blind to patient outcome. As a quality control in our genotyping analyses we will make random blind duplicates. In the case of the SCL6A4 gene, we selected the 5HTTLPR polymorphism. The triallelic system will be analyzed in two steps. First, to genotype $\mathrm{s}$ and $\mathrm{l}$ alleles, a region encompassing 5HTTLPR will be amplified, using the primers by Hilss et al. [41]. In the second step, fragments of La and Lg alleles will be identified using the 5'exonuclease assay (TaqMan SNP genotyping assay-by design) [42].

\section{Statistical analysis}

Demographic factors will be evaluated with the statistics program SPSS v.16. In addition, we will evaluate the Hardy-Weinberg Equilibrium (HWE) using Pearson's goodness-of-fit chi-squared test. The $\mathrm{p}$ value will be corrected according to the number of comparisons made in each locus. Also, the chi-squared test or Fisher's exact test will be used to compare genotype and allele frequencies between control and case groups. The Quanto 1.2 software will measure the sample size of the association. For all the association analyses the level of significance will be set at $p=0.05$ and the confidence interval at $95 \%$.

\section{Discussion}

Suicide is a major public problem around the world. Reports from the World Health Organization (WHO) indicate that suicide accounts for the largest share of self-harm in developed countries. Suicide is foreseen as an even greater contributor to the global burden of disease over the coming decades [5-7]. In Mexico, it is one of the five leading causes of death in 34 years old and the third in individuals between 15 and 24 years of age. Previous studies have reported that between $2.5 \%$ and $4.3 \%$ of the Mexican population have presented a suicide attempt at some time in their lives. In 2008, in Mexico, 6601210 inhabitants had experienced suicidal ideation $[4,8,43,44]$. Because the presence of psychiatric illnesses, such as anxiety disorders, depression, substance abuse (alcohol and drug dependence), personality disorders, schizophrenia and panic disorder do not fully explain suicidal behavior, a role for a genetic basis has been suggested in the pathology of SB $[45,46]$. In association studies, the most studied genes are those encoding proteins involved in the metabolism of serotonin such as tryptophan hydroxylase (TPH 1 and TPH 2), serotonin transporter (5-HTT), 5 mono-amine-oxidase (MAO-A), as well as the serotonin receptors, especially HTR1A, HTR1A, HTR2A and HTR2C. Although several genetic association studies have been undertaken in populations worldwide, progress has been slow since the predisposition to commit suicide does not follow a common Mendelian inheritance pattern.

Suicidal behavior has increased substantially in Mexico, and this rise can not be explained solely by environmental factors. Although there are several reports on this issue in Mexico, to date there are no studies evaluating the role for a serotonergic pathway in association with suicidal behavior. Genetic research conducted in Mexico will try to establish the regulation of genes in the pathology of SB.

\section{Abbreviations}

WHO: World Health Organization; SB: Suicidal behavior; 5-HIIA: 5-

hydroxyindoleacetic acid concentration; HTR2A: Serotonin 2A receptor; HTR2C: Serotonin 2C receptor; HTR1A: serotonin 1A receptor; HTR1B: Serotonin 1B receptor; TPH-1: Tryptophan hydroxylase 1; TPH2: Tryptophan hydroxylase 2; HWE: Hardy-Weinberg Equilibrium.

\section{Competing interests}

The authors declare that they have no competing interests.

\section{Authors' contributions}

TZC and JRI conceived the study, participated in the design and helped to draft the manuscript. PGS, VSMP and VSM helped to select the clinical criteria for patients. GA, NH, GCTB and MLLN helped to select the genes and polymorphisms in the study. TZCA, GCTB and JSMA wrote the draft of the manuscript. All authors read, critically revised, and approved the final version of the manuscript.

\section{Acknowledgements}

The present protocol will be supported by CONACYT (CB-2012-177459). This document is part of a larger study entitled: Estudio epigenético y genético en genes de la vía serotoninérgica en pacientes con intento de suicidio (Epigenetic and genetic study of genes of the serotonergic pathway in patients with attempted suicide). This study will involve two hospitals in Tabasco, Mexico: "Hospital General de Comalcalco, Tabasco, México" and "Hospital de Alta Especialidad Gustavo A. Rovirosa P, Villahermosa, Tabasco, México". 


\section{Author details}

'División Académica Multidisciplinaria de Comalcalco, Ranchería Sur, Cuarta Sección, CP 86650 Comalcalco, Tabasco, México. ²Universidad Juárez Autónoma de Tabasco, División Académica de Ciencias de la Salud, Villahermosa, Tabasco, México. ${ }^{3}$ Hospital General de Comalcalco, Tabasco, Secretaría de Salud, Comalcalco, Tabasco, México. ${ }^{4}$ Hospital de Alta Especialidad "Gustavo A. Rovirosa P", Villahermosa, Tabasco, México. ${ }^{5}$ Instituto Nacional de Medicina Genómica (INMEGEN), Servicios de Atención Psiquiátrica (SAP), Secretaría de Salud, México, DF, México. ${ }^{6} \mathrm{CIGEN}$, Centro de Investigación Genómica, Comalcalco, Tabasco, México. ${ }^{7}$ Hospital General de Yajalón, Yajalón, Chiapas, México.

Received: 27 January 2014 Accepted: 3 February 2014

Published: 5 February 2014

\section{References}

1. Krug EG, Dahlberg TT, Mercy JA, Zwi AB, Lozano R (Eds): World Report on Violence and Health. Geneva: World Health Organization; 2002.

2. Wasserman D, Terenius L, Wasserman J, Sokolowski M: The 2009 Nobel conference on the role of genetics in promoting suicide prevention and the mental health of the population. Mol Psychiatry 2010, 15(1):12-17.

3. Sokolowski M, Ben-Efraim YJ, Wasserman J, Wasserman D: Glutamatergic GRIN2B and polyaminergic ODC1 genes in suicide attempts: associations and gene-environment interactions with childhood/adolescent physical assault. Mol Psychiatry 2013, 18(9):985-992.

4. Borges G, Orozco R, Rafful C, Miller E, Breslau J: Suicidality, ethnicity and immigration in the USA. Psychol Med 2012, 42(6):1175-1184.

5. Mina Valdes A: [Suicidal intentions and suicides in Mexico, 1977-1984]. Estud Demogr Urbanos Col Mex 1991, 6(2):435-463.

6. Borges G, Benjet C, Medina-Mora ME, Orozco R, Familiar I, Nock MK, Wang PS: Service use among Mexico City adolescents with suicidality. J Affect Disord 2010, 120(1-3):32-39.

7. Borges G, Breslau J, Su M, Miller M, Medina-Mora ME, Aguilar-Gaxiola S: Immigration and suicidal behavior among Mexicans and Mexican Americans. Am J Public Health 2009, 99(4):728-733.

8. Borges G, Orozco R, Benjet C, Medina-Mora ME: [Suicide and suicidal behaviors in Mexico: retrospective and current status]. Salud Publica Mex 2010, 52(4):292-304

9. Puentes-Rosas E, Lopez-Nieto L, Martinez-Monroy T: [Mortality from suicides: Mexico, 1990-2001]. Rev Panam Salud Publica 2004, 16(2):102-109.

10. Mann JJ: Neurobiology of suicidal behaviour. Nat Rev Neurosci 2003, 4(10):819-828

11. Bondy B, Buettner A, Zill P: Genetics of suicide. Mol Psychiatry 2006, 11(4):336-351

12. Purselle DC, Nemeroff CB: Serotonin transporter: a potential substrate in the biology of suicide. Neuropsychopharmacology 2003, 28(4):613-619.

13. Turecki $G$, Ernst $C$, Jollant F, Labonte $B$, Mechawar N: The neurodevelopmental origins of suicidal behavior. Trends Neurosci 2012, 35(1):14-23.

14. Fu Q, Heath AC, Bucholz KK, Nelson EC, Glowinski AL, Goldberg J, Lyons MJ, Tsuang MT, Jacob T, True MR, et al: A twin study of genetic and environmental influences on suicidality in men. Psychol Med 2002, 32(1):11-24.

15. Kim CD, Seguin M, Therrien N, Riopel G, Chawky N, Lesage AD, Turecki G: Familial aggregation of suicidal behavior: a family study of male suicide completers from the general population. Am J Psychiatry 2005, 162(5):1017-1019.

16. Voracek M: Genetic factors in suicide: reassessment of adoption studies and individuals' beliefs about adoption study findings. Psychiatr Danub 2007, 19(3):139-153.

17. Roy A, Agren H, Pickar D, Linnoila M, Doran AR, Cutler NR, Paul SM: Reduced CSF concentrations of homovanillic acid and homovanillic acid to 5-hydroxyindoleacetic acid ratios in depressed patients: relationship to suicidal behavior and dexamethasone nonsuppression. Am J Psychiatry 1986, 143(12):1539-1545.

18. Traskman L, Asberg M, Bertilsson L, Sjostrand L: Monoamine metabolites in CSF and suicidal behavior. Arch Gen Psychiatry 1981, 38(6):631-636.

19. Asberg M, Traskman L, Thoren P: 5 -HIAA in the cerebrospinal fluid. A biochemical suicide predictor? Arch Gen Psychiatry 1976, 33(10):1193-1197.

20. Mann JJ, Arango V, Underwood MD: Serotonin and suicidal behavior. Ann N Y Acad Sci 1990, 600:476-484.
21. Molcho A, Stanley B, Stanley M: Biological studies and markers in suicide and attempted suicide. Int Clin Psychopharmacol 1991, 6(2):77-92.

22. Anguelova $\mathrm{M}$, Benkelfat $\mathrm{C}$, Turecki $\mathrm{G}$ : A systematic review of association studies investigating genes coding for serotonin receptors and the serotonin transporter: II. Suicidal behavior. Mol Psychiatry 2003, 8(7):646-653.

23. De Luca V, Zai G, Tharmalingam S, de Bartolomeis A, Wong G, Kennedy JL: Association study between the novel functional polymorphism of the serotonin transporter gene and suicidal behaviour in schizophrenia. Eur Neuropsychopharmacol 2006, 16(4):268-271.

24. Helbecque N, Sparks DL, Hunsaker JC 3rd, Amouyel P: The serotonin transporter promoter polymorphism and suicide. Neurosci Lett 2006, 400(1-2):13-15.

25. Zalsman G, Patya M, Frisch A, Ofek H, Schapir L, Blum I, Harell D, Apter A, Weizman A, Tyano S: Association of polymorphisms of the serotonergic pathways with clinical traits of impulsive-aggression and suicidality in adolescents: a multi-center study. World I Biol Psychiatry 2011, 12(1):33-41.

26. Pungercic G, Videtic A, Pestotnik A, Pajnic IZ, Zupanc T, Balazic J, Tomori M, Komel R: Serotonin transporter gene promoter (5-HTTLPR) and intron 2 (VNTR) polymorphisms: a study on Slovenian population of suicide victims. Psychiatr Genet 2006, 16(5):187-191.

27. Mann JJ, Huang YY, Underwood MD, Kassir SA, Oppenheim S, Kelly TM, Dwork AJ, Arango V: A serotonin transporter gene promoter polymorphism (5-HTTLPR) and prefrontal cortical binding in major depression and suicide. Arch Gen Psychiatry 2000, 57(8):729-738.

28. Lesch KP, Bengel D, Heils A, Sabol SZ, Greenberg BD, Petri S, Benjamin J, Muller CR, Hamer DH, Murphy DL: Association of anxiety-related traits with a polymorphism in the serotonin transporter gene regulatory region. Science 1996, 274(5292):1527-1531.

29. Serretti A, Mandelli L, Giegling I, Schneider B, Hartmann AM, Schnabel A, Maurer K, Moller HJ, Rujescu D: HTR2C and HTR1A gene variants in German and Italian suicide attempters and completers. Am J Med Genet B Neuropsychiatr Genet 2007, 144B(3):291-299.

30. Ohtani M, Shindo S, Yoshioka N: Polymorphisms of the tryptophan hydroxylase gene and serotonin $1 \mathrm{~A}$ receptor gene in suicide victims among Japanese. Tohoku J Exp Med 2004, 202(2):123-133.

31. Nishiguchi N, Shirakawa O, Ono H, Nishimura A, Nushida H, Ueno Y, Maeda K: Lack of an association between 5-HT1A receptor gene structural polymorphisms and suicide victims. Am J Med Genet 2002, 114(4):423-425.

32. Hong CJ, Pan GM, Tsai SJ: Association study of onset age, attempted suicide, aggressive behavior, and schizophrenia with a serotonin $1 \mathrm{~B}$ receptor (A-161 T) genetic polymorphism. Neuropsychobiology 2004, 49(1):1-4.

33. De Luca V, Tharmaligam S, Strauss J, Kennedy JL: 5-HT2C receptor and MAO-A interaction analysis: no association with suicidal behaviour in bipolar patients. Eur Arch Psychiatry Clin Neurosci 2008, 258(7):428-433.

34. Lyddon R, Dwork AJ, Keddache M, Siever LJ, Dracheva S: Serotonin $2 c$ receptor RNA editing in major depression and suicide. World J Biol Psychiatry 2012, 9:9.

35. Antypa N, Serretti A, Rujescu D: Serotonergic genes and suicide: a systematic review. Eur Neuropsychopharmacol 2013, 23(10):1125-1142.

36. Arango V, Huang YY, Underwood MD, Mann JJ: Genetics of the serotonergic system in suicidal behavior. J Psychiatr Res 2003, 37(5):375-386.

37. Bortolato M, Pivac N, Muck Seler D, Nikolac Perkovic M, Pessia M, Di Giovanni G: The role of the serotonergic system at the interface of aggression and suicide. Neuroscience 2013, 236:160-185.

38. Gonzalez-Castro TB, Tovilla-Zarate C, Juarez-Rojop I, Pool Garcia S, Genis A, Nicolini H, Lopez Narvaez L: Distribution of the Val108/158Met polymorphism of the COMT gene in healthy Mexican population. Gene 2013 526(2):454-458.

39. Tovilla-Zarate C, Juarez-Rojop I, Ramon-Frias T, Villar-Soto M, Pool-Garcia S, Medellin BC, Genis Mendoza AD, Narvaez LL, Humberto N: No association between COMT val158met polymorphism and suicidal behavior: metaanalysis and new data. BMC Psychiatry 2011, 11(151):11-151.

40. Tovilla-Zarate C, Medellin BC, Fresan A, Lopez-Narvaez L, Castro TB, Juarez Rojop I, Ramirez-Bello J, Genis A, Nicolini H: No association between catechol-o-methyltransferase Val108/158Met polymorphism and schizophrenia or its clinical symptomatology in a Mexican population. Mol Biol Rep 2013, 40(2):2053-2058.

41. Heils A, Teufel A, Petri S, Stober G, Riederer P, Bengel D, Lesch KP: Allelic variation of human serotonin transporter gene expression. $J$ Neurochem 1996, 66(6):2621-2624. 
42. Gudayol-Ferré E, Herrera-Guzmán I, Camarena B, Cortés-Penagos C, HerreraAbarca JE, Martínez-Medina P, Cruz D, Hernández S, Genis A, CarrilloGuerrero MY, et al: The role of clinical variables, neuropsychological performance and SLC6A4 and COMT gene polymorphisms on the prediction of early response to fluoxetine in major depressive disorder. $J$ Affect Disord 2010, 127(1-3):343-351.

43. Chavez-Hernandez AM, Paramo D, Leenaars AA, Leenaars L: Suicide notes in Mexico: what do they tell us? Suicide Life Threat Behav 2006, 36(6):709-715.

44. Borges G, Rosovsky H, Gomez C, Gutierrez R: [Epidemiology of suicide in Mexico, 1970-1984]. Salud Publica Mex 1996, 38(3):197-206.

45. Gonzalez-Castro TB, Tovilla-Zarate C, Juarez-Rojop I, Pool Garcia S, Velazquez-Sanchez MP, Genis A, Nicolini H, Lopez Narvaez L: Association of the 5HTR2A gene with suicidal behavior: case-control study and updated meta-analysis. BMC Psychiatry 2013, 13(25):13-25.

46. Gonzalez-Castro TB, Tovilla-Zarate CA, Juarez-Rojop I, Pool Garcia S, Genis A, Nicolini H, Lopez Narvaez L: Association of 5HTR1A gene variants with suicidal behavior: case-control study and updated meta-analysis. J Psychiatr Res 2013, 47(11):1665-1672.

doi:10.1186/1471-244X-14-29

Cite this article as: Tovilla-Zárate et al: Study on genes of the serotonergic system and suicidal behavior: protocol for a case-control study in Mexican population. BMC Psychiatry 2014 14:29.

\section{Submit your next manuscript to BioMed Central and take full advantage of:}

- Convenient online submission

- Thorough peer review

- No space constraints or color figure charges

- Immediate publication on acceptance

- Inclusion in PubMed, CAS, Scopus and Google Scholar

- Research which is freely available for redistribution 